\title{
GAMBARAN PENGETAHUAN KELUARGA TENTANG PERAWATAN PASIEN STROKE
}

\author{
Siti Kurniasih ${ }^{1)}$, Ariani Fatmawati ${ }^{2)}$, Perla Yualita $^{3)}$ \\ ${ }^{1)}$ Rumah Sakit Al-Islam Bandung; Jl. Soekarno Hatta No. 644 Bandung \\ ${ }^{2,3)}$ STIKes Aisyiyah Bandung; Jl. K.H. Ahmad Dahlan Dalam No.6 Bandung \\ e-mail: rianiners@gmail.com
}

\begin{abstract}
ABSTRAK
Perawatan pasien stroke dimulai sejak dalam perawatan di rumah sakit hingga setelah selesai dirawat. Pengetahuan keluarga dalam merawat pasien stroke di rumah perlu ditingkatkan. Tujuan dari penelitian ini adalah mengetahui gambaran pengetahuan keluarga tentang perawatan pasien stroke di ruang rawat inap RSAI Bandung. Jenis penelitian yang digunakan deskriptif kuantitatif, yang melibatkan 60 orang keluarga pasien yang berusia lebih dari 18 tahun, tinggal serumah dengan pasien dan terlibat dalam perawatan pasien. Teknik pengambilan sampel menggunakan purposive sampling. Penelitian dilakukan di Rumah Sakit Al Islam Bandung pada tanggal 1-24 Januari 2019. Instrumen yang digunakan adalah modifikasi assessment caregiver knowledge dan Indeks Barthel. Analisis yang digunakan distribusi frekuensi. Hasil penelitian menunjukan bahwa tingkat pengetahuan keluarga pada pasien stroke kategori cukup sebanyak 31,5\% dan kurang sebanyak 68,5\%. Peneliti menyarankan optimalisasi terhadap program discharge planning yang sudah ada dengan melakukan kajian-kajian kebutuhan pasien dan keluarga serta proses edukasi secara lebih intensif tidak hanya pada pasien akan tetapi pada keluarganya.
\end{abstract}

Kata Kunci : Keluarga; Pasien stroke; Perawatan Pasien Stroke

\begin{abstract}
Stroke patients treatment started during treatment at the hospital until after being treated. Family knowledge in treating stroke patients at home needs to be improved. The purpose of this study is to find out the description of family knowledge about the care of stroke patients at Al-Islam Hospital Bandung. This research used quantitative descriptive, involving 60 respondents of patients aged over 18 years, living with the patient and engaging in care of patient. The sample use purposive sampling technique. The study was conducted at Al-Islam Hospital Bandung on 1-24 January 2019. The instrument used was a modification of the assessment of the caregiver knowledge and Barthel Index. The analysis used frequency distribution. The results showed that the level of family knowledge in stroke patients in the category was sufficient as much as $31.5 \%$ and less as much as $68.5 \%$. Researchers suggest optimizing the existing discharge planning program by conducting studies of the needs of patients and families as well as an intensive education process not only for patients but for their families.
\end{abstract}

Keyword : Family; Stroke Patien; Stroke Patient Care

Jurnal Kesehatan Holistic/ Volume 4/ Nomor 1/Januari 2020

(ISSN: 2548-1843, EISSN: 2621-8704) 


\section{PENDAHULUAN}

Stroke adalah salah satu masalah kesehatan utama di dunia. Stroke merupakan penyebab kematian ketiga di dunia setelah penyakit jantung coroner dan kanker (American Heart Association, 2015). Penyakit stroke baik iskemik maupun hemoragik dapat menimbulkan dampak terhadap penderitanya. Dampak tersebut berupa gangguan fungsi motorik, sensorik, kognitif dan komunikasi baik secara singular ataupun kombinasi (Williams, Perry, \& Watkins, 2010).

Sebagian besar pasien stroke mengalami kelemahan pada salah satu sisi tubuhnya atau hemiparese (Scbachter and Cramer, 2013). Kelemahan anggota gerak pada penderita stroke dapat memengaruhi kemampuan mobilisasi dan kontraksi ototnya (Andarwati, 2013). Kondisi ini menyebabkan penderita mengalami keterbatasan/ dissability dalam pemenuhan kebutuhan aktivitas sehari-hari.

Perawatan pasien stroke dimulai sejak dalam perawatan rumah sakit hingga pascarawat. Perawatan tersebut harus komprehensif sehingga mampu meningkatkan, mempertahankan, memulihkan kesehatan bahkan memaksimalkan tingkat kemandirian serta mengurangi risiko disabilitas atau komplikasi. Proses tersebut sangat dipengaruhi oleh kemampuan keluarga dalam menjalankan fungsinya. Keluarga harus memahami dan memiliki kemampuan dalam melaksanakan fungsi pemberi perawatan kesehatan terhadap anggotanya yang sakit (Friedman et all, 2010). Keluarga atau pengasuhnya merupakan kunci utama dalam perawatan pasien pasca-stroke (Pitthayapong et al, 2017).

Peran keluarga dalam merawat pasien pasca-stroke di rumah yaitu meningkatkan kemampuan pasien untuk mandiri, pemenuhan kebutuhan ADL, meningkatkan rasa percaya diri pasien, meminimalkan kecacatan serta mencegah terjadinya stroke berulang. Penelitian Van Eedden, Van Heugten, dan Evers, (2012) menyebutkan bahwa sebanyak $34 \%$ biaya perawatan kesehatan di negara-negara barat 
dihabiskan untuk perawatan stroke ulang dan komplikasi pasca-stroke.

Penelitian Rachmawati, Andarini, dan Ningsih (2017) dan Allo (2015) menyebutkan bahwa sebagian keluarga pasien stroke mempunyai pengetahuan yang kurang tentang faktor risiko dan peringatan gejala stroke yang dapat menyebabkan keluarga tidak segera membawa pasien ke rumah sakit atau instalasi gawat darurat. Peran perawat dalam rehabilitasi pasien stroke adalah sebagai pendidik dan fasilitator bagi keluarga dalam program perawatan di rumah pasien stroke. Peran perawat sebagai pendidik, perawat bertanggung jawab memberikan edukasi terhadap pasien dan keluarga untuk meningkatkan kemampuan pasien menjalankan perawatan di rumah (Sutoyo, 2012).

Berdasarkan data dari rekam medis, pasien yang menderita stroke di ruang rawat inap RSAI dari bulan Januari-Maret 2018 sebanyak 278 orang, bulan April-Juni 2018 sebanyak 287 orang dan terjadi peningkatan lagi pada bulan JuliSeptember 2018 sebanyak 335 orang.
Jumlah lama rawat lebih dari seminggu.

Discharge planing sudah dilakukan dengan memberikan penyuluhan kesehatan oleh perawat, dokter, gizi, farmasi dan fisiotherapi kepada keluarga pasien stroke. tapi dokumentasi yang khusus berupa leaflet tentang perawatan pasien stroke dirumah yang bisa menjadi panduan keluarga dalam merawat pasien stroke belum ada dan juga belum adanya program home visite untuk mengevaluasi sejauhmana pelaksanaan perawatan dirumah yang dilakukan oleh keluarga untuk merawat pasien stroke secara berkelanjutan.

Sesuai fenomena di atas peneliti tertarik untuk melakukan penelitian tentang gambaran pengetahuan keluarga dalam merawat pasien pasca-stroke di rumah sebagai upaya meningkatkan pelayanan yang berkesinambungan dan mengetahui pengetahuan anggota keluarga dalam merawat pasien yang menderita stroke. 


\section{METODE}

Jenis penelitian yang digunakan adalah deskriptif kuantitatif. Populasi dalam penelitian berjumlah 112. Metode sampling yang digunakan pada penelitian ini adalah purposive sampling. Jumlah sampel sebanyak 60 dengan kriteria inklusi keluarga yang berusia lebih dari 18 tahun, tinggal bersama pasien, mau merawat pasien, mampu berkomunikasi dan bersedia menjadi responden dalam penelitian ini. Penelitian ini dilakukan di RS AlIslam Bandung pada tanggal 1-24 Januari 2019.

Instrumen penelitian yang digunakan yaitu modifikasi assessment caregiver knowledge (Lee et al, 2014; Amritha, 2009). Instrumen ini terdiri dari 26 pertanyaan dengan skala guttman. Instrumen kedua yaitu indeks barthel yang terdiri dari 10 pertanyaan. Analisis data yang digunakan pada penelitian ini menggunakan analisi distribusi frekuensi. Etika pada penelitian ini dilakukan dengan memenuhi aspek beneficence, non maleficence, dan justice.

\section{HASIL DAN PEMBAHASAN}

Hasil analisis penelitian ini diperlihatkan melalui tabel di bawah ini:

Tabel 1

Distribusi frekuensi Karakteristik Responden di Ruang Rawat Inap RSAI

\begin{tabular}{lcc}
\multicolumn{3}{c}{ Bandung $(\mathrm{n}=60)$} \\
\hline \multicolumn{1}{c}{ Variabel } & f & \% \\
\hline Usia & & \\
$<36$ tahun & 14 & 23,3 \\
36-45 tahun & 21 & 35 \\
46-55 ahun & 15 & 25 \\
$>55$ tahun & 10 & 16,7 \\
\hline Frekuensi Stroke & & \\
Baru pertama & 48 & 80 \\
Kedua & 7 & 11,7 \\
Ketiga & 1 & 1,67 \\
Keempat & 4 & 6,67 \\
\hline Sumber Informasi & & \\
Media & 7 & 11,7 \\
Teman/tetangga & 5 & 8,33 \\
Tenaga kesehatan & 14 & 23,3 \\
Belum pernah dapat & 34 & 56,7 \\
\hline
\end{tabular}

Berdasarkan tabel 1 usia keluarga yang merawat pasien stroke paling banyak berada pada usia dewasa madya (36-45\%) sebanyak $35 \%$. Pasien stroke yang dirawat paling banyak baru pertama kali mengalami stroke sebanyak $80 \%$. Setengah dari keluarga yang merawat pasien stroke belum pernah mendapatkan informasi mengenai perawatan pada pasien stroke sebanyak $56,7 \%$.

Notoatmodjo (2010) menyatakan bahwa usia seseorang akan memengaruhi daya tangkap dan pola pikir seseorang terhadap informasi 
yang diberikan, semakin bertambah usia maka daya tangkap dan pola pikir seseorang berkembang. Ambarwati dkk (2009) yang menyatakan sebagian besar responden bahwa usia 54-67 sebesar $54,2 \%$ memiliki pengetahuan dengan katagori sedang sebesar 70,8 $\%$ dan yang memiliki pengetahaun baik $29,2 \%$ dan sebagai responden sudah punya pengalaman merawat pasien stroke selama 6 bulan.

Tabel 2

Distribusi Tingkat Pengetahuan Keluarga tentang Caregiver di Ruang Rawat Inap RSAI Bandung ( $\mathrm{n}=60)$

\begin{tabular}{ccc}
\hline Karakteristik & f & \% \\
\hline Tingkat Pengetahuan & & \\
Baik & 0 & 0 \\
Cukup & 19 & 32 \\
Kurang & 41 & 68 \\
\hline
\end{tabular}

Berdasarkan tabel 2 didapatkan bahwa pengetahuan keluarga tentang caregiver masih dengan persentase sebanyak $68 \%$ dan sudah memiliki cukup pengetahuan sebanyak $32 \%$.

Berdasarkan hasil penelitian responden memiliki pengetahuan yang kurang sebesar $68 \%$. Hasil ini dikarenakan hampir $80 \%$ responden merawat pasien stroke pertama kali (pengalaman pertama) dan sebagian besar responden belum pernah mendapat informasi tentang cara perawatan pasien stroke dirumah sebesar $56,7 \%$.

Kurangnya pengetahuan keluarga akan menimbulkan kegagalan perawatan pasien stroke di rumah. Pengetahuan keluarga yang tinggi memiliki sikap positif dalam merawat pasien stroke (Vonna, 2015). Sementara keluarga yang kurang mampu merawat memiliki pengetahuan rendah dan memiliki sikap yang negatif (Lee et al, 2014; Simandalahi, 2017). Peran keluarga dalam proses rehabilitasi pasien selain sebagai caregiver adalah sebagai edukator dan motivator (Festy, 2009).

Pengetahuan keluarga dalam merawat pasien stroke dipengaruhi oleh pengalaman merawat pasien stroke. Hasil menunjukkan bahwa $80 \%$ pasien pertama kali menderita stroke. Penelitian Alyaa et all (2015) menyebutkan bahwa keluarga yang sudah lama melakukan perawatan terhadap pasien sebanding dengan tingkat pengetahuannya. Selain pengalaman, pengetahuan juga dipengaruhi oleh informasi. 
Hasil penelitian menunjukkan bahwa sebanyak $56,7 \%$ responden belum mendapatkan informasi tentang perawatan pasien stroke. Penelitian Sahmad (2015) menyatakan bahwa responden sebelum mendapatkan penyuluhan discharge planning melalui $\mathrm{CD}$ rata-rata pengetahuan responden 9,45 adapun sesudah mendapatkan penyuluhan discharge planning melalui CD ada peningkatan pengetahuan rata-rata sebesar 15,33.

Penelitian yang dilakukan Wahyuni dkk (2018) dalam penelitiannya menunjukkan bahwa pendidikan kesehatan dengan media booklet tentang terapi wicara memiliki pengaruh yang signifikan untuk meningkatkan pengetahuan keluarga dan sikap keluarga dalam membantu anggota keluarga yang menderita stroke. Tatali dkk (2018) dalam penelitiannya menyatakan adanya hubungan dukungan keluarga dengan tingkat kemandirian Activity Daily Living pada pasien pasca-stroke.

\section{KESIMPULAN DAN SARAN}

Berdasarkan pembahasan dari hasil penelitian mengenai tingkat pengetahuan keluarga dalam merawat pasien stroke, maka didapat simpulan: karakteristik reponden yang menjadi subjek berjumlah 60 orang berusia 3645 tahun sebesr 35 $\%$, pasien stroke baru pertama kali menderita stroke sebesar $80 \%$, baru merawat pasien stroke sebesar $80 \%$, serta belum pernah mendapat informasi tentang cara perawatan pasien stroke dirumah sebesar 56,7 $\%$. Tingkat pengetahuan keluarga pada pasien stroke di rumah ada pada kategori cukup $(31,5 \%)$ dan kurang $(68,5 \%)$.

Saran yang diajukan oleh peneliti bagi Rumah Sakit adalah dengan melakukan optimalisasi program discharge planning dengan melakukan kajian-kajian kebutuhan pasien dan keluarga. Membuat program home visite atau sistem rujukan balik. Saran peneliti bagi bagi Perawat. 
Perawat pelaksana seyogyanya melakukan proses edukasi secara lebih intensif tidak hanya pada pasien akan tetapi pada keluarganya. Edukasi didasarkan pada SAP (satuan acara penyuluhan) yang detail dan disertai metode dan media yang tepat berupa leaflet yang khusus perawatan pasien stroke dirumah.

\section{DAFTAR PUSTAKA}

Allo, O. A. (2015) Hubungan Pengetahuan Keluarga Tentang Penyakit Stroke Dengan Dukungan Keluarga Dalam Merawat Pasien Stroke Di Ruang Rawat Interna RSUD Lakipadada Tahun 2015. Jurnal AgroSainT VI (3).

Alyaa, M.F., Hi, M.Y., Khairina, I.N., Aisyah, N.S.A,, Tan, C.E., Firzah, A.A. (2015). The Level Of Caregiving Knowledge And Self-Efficacy Among Caregivers Of Stroke Patient. Universiti Kebangsaan Malaysia Medical Centre (UKMMC).

Ambarwati dkk. (2009) Hubungan Antara Pengetahuan Dan Sikap Keluarga Dengan perilaku Dalam Meningkatkan Kapasitas
Fungsional Pasien Pasca-Stroke

Di Wilayah Kerja Puskesmas Kartasura. Berita Ilmu Keperawatan ISSN Vol. 2 No. 2 hal. 63-68.

American Heart Association (2015). Let's talk about ischemic stroke. www.strokeassociation.org/idc/g roups/strokepublic/@wcm/.../ucm _ 309725.pdf diakses 12 september 2019.(12.00).

Amritha. (2009). Knowledge Assessment Of Caregivers Of Stroke Patients About Their Caring Role. Sree Chitra Tirunal Institute For Medical Sciences And Tecnology Trivandrum.

Andarwati, N.A. (2013). Pengaruh Latihan Rom Terhadap Peningkatan Kekuatan Otot Pasien Hemiparese Post Stroke Di Rsud Dr. Moewardi Surakarta. Fakultas Ilmu Kesehatan Universitas Muhammadiyah Surakarta.

Festy. P. (2009). Peran Keluarga Dalam Pelaksanaan Rehabilitasi Medik Pada Pasien Stroke. Jurnal keperawatan UMSurabaya. 32-36. 
Friedman, M., Bowden, V. R., Jones, E. G. (2010). Buku Ajar Keperawatan Keluarga : Riset, Teori dan Praktik. Alih Bahasa: Hamid, Achir Yani S. Et al. Jakarta. EGC Medical Publisher.

Lee, K.W., Choi, S.J., Kim, S.B., Lee, J.H., Lee, S.J. (2014). A Survey of Caregivers' Knowledge About Caring for Stroke Patients. Annals of Rehabilitation Medicine. 39(5):800-815.

Notoatmodjo, S. (2010). Promosi Kesehatan dan Ilmu Perilaku. Jakarta : Rineka Cipta.

Pitthayapong, S., Thiangtam, W., Powwattana, A., Leelacharas, S., \& Waters, C. M. (2017). A Community Based Program for Family Caregivers for Post Strok Survivors in Thailand. Asian Nursing Research, 11(2), 150157.

Rachmawati, Andarini, dan Ningsih (2017). Pengetahuan Keluarga Berperan Terhadap keterlambatan Kedatangan Pasien Stroke Iskemik Akut Di Instalasi Gawat Darurat. Jurnal Kedokteran Brawijaya. 29. (4).
Sahmad . (2015). Potensi Peran Keluarga Dalam Perawatan Penyakit Stroke Melalui Pengembangan Model Discharrge Planning Berbasis Teknologi Informatika. Jurusan Keperawatan Politeknik Kesehatan Kemenkes Kendari. Jurnal MKMI hal 154-159.

Scbaechter and Crimer. (2013). Effect of Experience After Stroke on Brain and Behavior. Neurology Report Vol. 27.

Simandalahi, T. (2017). Analisis Hubungan Tingkat Pengetahuan dan Sikap Keluarga dengan Kemampuan Keluarga Merawat Pasien Pasca Stroke. Jurnal Syedzasaintika. 9 (1) : 41-48.

Sutoyo, A. (2012). Pemahaman Individu. Yogyakarta: Pustaka Pelajar.

Van Eeden M., Van Heugten C.M., and Severs S.A. (2012). The economic impact of stroke in The Netherlands: the $€$ restore4stroke study. BMC Public Health. 12:122.

Vonna dan Puteri. (2015). Hubungan Pengetahuan Dengan Sikap 
Keluarga Dalam Merawat

Anggota Keluarga Yang

Menderita Stroke Di Wilayah

Kerja Puskesmas Mutiara

Kecamatan Mutiara Timur

Kabupaten Pidie. Jurnal S-1

Kesehatan Masyarakat Fakultas

Ilmu Kesehatan, Universitas

Ubudiyah Indonesia .
Wahyuni dkk. (2018). Pendidikan Kesehatan Media Booklet terhadap Pengetahuan dan Sikap Keluarga Tentang Speech Therapy pada Pasien Stroke di IRNA Seruni A RSUD Dr. Soetomo Surabaya. Universitas Airlangga. Jurnal Ners Lentera. Vol. 6 (1).

Williams, J., Perry, L., \& Watkins, C. (Eds.). (2010). Acute Stroke Nursing. UK: Wley-Blackwell. 